\title{
Dryudella paulinae spec. nov. (Hymenoptera, Crabronidae) from Morocco
}

With 7 figures and 1 key

HANS-JOACHIM JACOBS ${ }^{1,2,5}$ and SWANTJE GRABENER ${ }^{3,4}$

${ }^{1}$ Dorfstraße 41, 17495 Ranzin, Germany - jacobs.hym@gmx.de

2 Senckenberg Deutsches Entomologisches Institut, Eberswalder Straße 90, 15374 Müncheberg, Germany

${ }^{3}$ Biodiversity, Evolution and Ecology of Plants, Biocentre Klein Flottbek and Botanical Garden, University of Hamburg,

Ohnhorststraße 18, 22609 Hamburg, Germany

${ }^{4}$ Centrum für Naturkunde (CeNak), Zoologisches Museum, Martin-Luther-King-Platz 3, 20146 Hamburg, Germany

${ }^{5}$ Corresponding author

Published on 2017-06-30

DOI:'10.21248/contrib.entomol.67.1.111-115,

\section{Abstract}

Dryudella paulinae spec. nov. is described from Morocco. A concise key is presented, which differentiates D. paulinae from other Dryudella species.

\section{Nomenclatural acts}

Dryudella paulinae spec. nov. urn:lsid:zoobank.org:act:8D5ACFAB-85E7-422A

\section{Key words}

Astatinae, Dryudella, Maghreb, High Atlas, new species, key

\section{Zusammenfassung}

Dryudella paulinae spec. nov. aus Marokko wird beschrieben. Im Bestimmungsschlüssel wird D. paulinae von anderen Dryudella-Arten unterschieden.

\section{Introduction}

With 57 species, the genus Dryudella represents one of the medium sized genera of the diverse Crabronidae (Pulawski 2016). Dryudella has a Holarctic distribution, with the majority of species occurring in the Palearctic region. Until now, five species were recorded from Morocco (Pulawski 2016).

In the framework of her master thesis, Swantje Grabener collected flower visiting insects in southern parts of Morocco at the former BIOTA-Maroc (Biodiversity
Monitoring Transect Analysis in Morocco) test sites which are part of the BIOTA-Africa project funded by the German Federal Ministry of Education and Research (Grant no. 01 LC 0601A). Since 2001, this region is regularly visited by researchers and student excursions from the working group of Prof. Dr. Norbert Jürgens from the Biocentre Klein Flottbek, University of Hamburg, to study the vegetation dynamics. However, few studies have been undertaken to study the insect fauna at these test sites. 

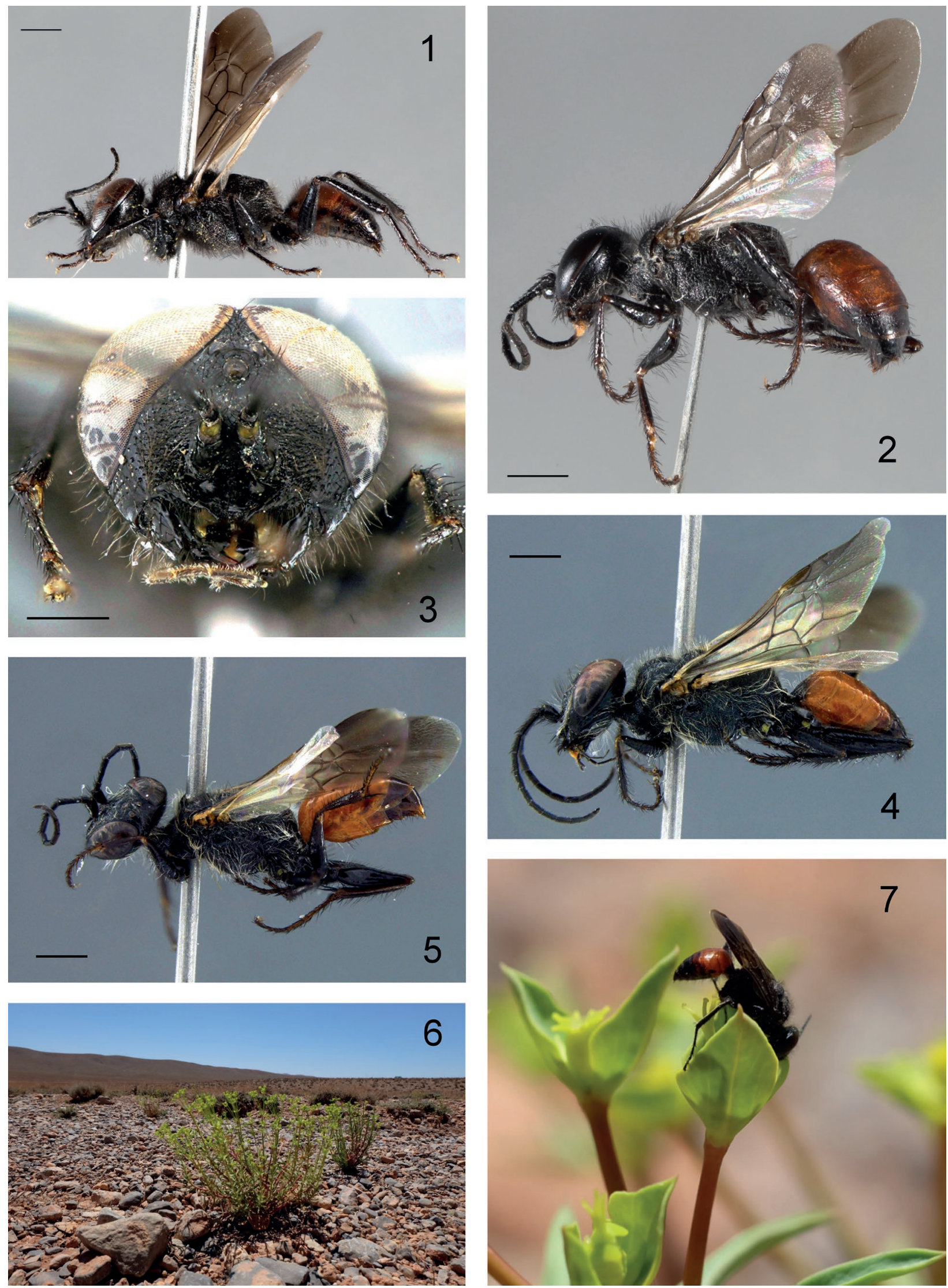

Plate 1: 1 - Dryudella paulinae spec. nov. ơ paratype. 2 - Dryudella paulinae spec. nov. ㅇ paratype. 3 - Dryudella paulinae spec. nov. $0^{\top}$ holotype head frontal. 4 - Dryudella nephertiti $0^{\star} .5$ - Dryudella nephertiti + .6 - Habitat of Dryudella paulinae spec. nov. 7 - Dryudella paulinae spec. nov. visiting Euphorbia (Photos 1, 2, 6, 7 S. Grabener, 3-5 H.-J. Jacobs). (scale bars $1 \mathrm{~mm}$ ). 
Seven specimens of an undescribed species of Dryudella SpINOLA, 1843 were found at the Taoujgalt plain. To enable identification, a dichotomous key to the species similar to this one is given based on descriptions and keys available in literature. Figures of Dryudella paulinae spec. nov. (o Fig. 1, o Fig. 2) and the similar D. nephertiti (Pulawski, 1959) (o Fig. 4, o Fig. 5) are presented.

\section{Material and methods}

The Taoujgalt plain is located in the Central High Atlas in the province Ouarzazate at an altitude of about $1,850 \mathrm{~m}$. The steppe-vegetation is dominated by Artemisia herbaalba Asso and is clearly affected by livestock grazing. The average precipitation per year lies at about $170 \mathrm{~mm}$ with an average temperature of $14.2{ }^{\circ} \mathrm{C}$ (SCHULz 2008). In spring 2016 when the specimens were collected it was comparatively dry and there were many Euphorbia species flowering in the small wadis (Fig. 6). These flowers were frequently visited by Dryudella males (Fig. 7). All specimens were collected either with a net directly from the Euphorbia flowers or by using UV-reflecting yellow pan traps.

Digital photos for Figs 1-2 were taken with the Visionary Digital Passport System with Canon EOS 60D camera with $65 \mathrm{~mm}$ macro lens (diameter $56 \mathrm{~mm}$ ). Composite images are created by Zerene Stacker software. Digital photos for Figs 3-5 were taken with a Leica DFC450 C camera attached to a Leica Z6 APO zoom system. Lighting was from a reversed LED ring light illuminating the specimens indirectly by reflecting diffused light from the inner surface of a styrofoam hemisphere set up around the specimen. Composite images were created using the software CombineZ5. Contrast and brightness of images was adjusted using the software PhotoImpact XL (Ulead Systems Inc.). Plates were mounted with PhotoImpact XL (Ulead Systems Inc.).

\section{Results and Discussion}

Diagnosis: The male of Dryudella paulinae spec. nov. is similar to D. nephertiti (Pulawski, 1959), D. sepulchralis (BEAUMONT, 1968) and D. unicolor SCHMID-EgGER, 2014 due to the lack of a white spot on the frons. It can be separated from $D$. sepulchralis and $D$. unicolor by the coloration of the abdomen (see key below). The female is similar to D. nephertiti. Both sexes of D. paulinae spec. nov. can be distinguished from $D$. nephertiti by the black setae on head and thorax (Figs 1,2), which are white in D. nephertiti (Figs 4, 5).

Description: Dryudella paulinae spec. nov.

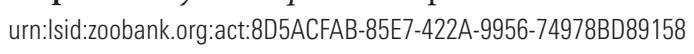

o - Body length 6.5-7.0 mm. Black, terga I-III and sterna I-II red, sometimes tergum III darkened. Vertical part of tergum I with black spot. Fore wing completely brownish darkened, wing venation and pterostigma dark brown. Hind wing hyaline with yellow venation, strongly contrasting with fore wing. Frons black, without yellow spot below ocelli. Antennomeres VI-VIII with pale linear tyloids, antennomere IX with a point shaped tyloid basally. Frons with shallow scattered pits on irregularly reticulate surface. Anterior margin of clypeus with two teeth, with round broad emargination between teeth (Fig. 3). Central part of clypeus smooth and shiny, with distinct scattered pits. Lateral part of clypeus with similar sculpture as frons. Mandible with large inner lobe (Fig. 3). Malar space 1.3 times as long as basal width of mandible. Frons with long erected black setae. Genae smooth and shiny, with scattered pits, and with long grey setae, setae nearly as long as malar space. Mesonotum irregular reticulate, central part of distal half smooth. Anterior part of scutellum smooth and shiny, posterior part reticulate. Mesopleuron reticulate, with striae and shallow pits between reticulate microsculpture. Epimeron with longitudinal wrinkles. Propodeal enclosure weakly limited from lateral parts of propodeum, strongly reticulate. Lateral parts of propodeum similarly reticulate as propodeal enclosure, without distinct longitudinal keels. Mesonotum and mesopleuron with long erect black setae, propodeum laterally and distally with long black and grey setae, propodeal enclosure with shorter white setae. Terga I-V with very fine microsculpture, tergum VI only basally with microsculpture, apically smooth and shiny, terga I-VI with very scattered shallow pits laterally, tergum VII with distinct pits laterally and distally. All legs with long black setae.

+ - Body length $6.0 \mathrm{~mm}$. Black, middle part of mandible, abdominal terga I-III and sterna I-III red. Wings as in male. Anterior margin of clypeus with two teeth. Pubescence, sculpture of thorax and abdomen as in male. Lateral parts of propodeum with indistinct longitudinal keels. Pygidial area smooth and shiny, with weakly concave margins.

Holotype o : "Morocco, Taojgalt, 31.38864, -6.3258, 10.04.2016, leg. S. Grabener", "SG-M 239", in coll. Senckenberg Deutsches Entomologisches Institut, Müncheberg, Germany (SDEI).

Paratypes: $5 \sigma^{\top} \sigma^{\star}$ "Morocco, Taojgalt, 31.38864, -6.3258, 10.04.2016, An:Euphorbia sp., leg. S. Grabener”, specimens with the IDs SG-M 240, 241, 242, 243, 244. 1 \% "Morocco, Taojgalt, $31.38864-6.3258,10.04 .2016$, Farbschale 3 gelb, leg. S. Grabener", "SG-M 971". Paratypes in SDEI, coll. Zoologisches Museum der Universität Hamburg, coll. Jacobs (Ranzin), coll. Grabener (Hamburg), coll. SchmidEgger (Berlin) (all depositories are in Germany).

\section{Distribution: Southern Morocco.}

Etymology: The species is dedicated to Paulina Zigelski, who accompanied Swantje Grabener during her field work in Morocco. 


\section{Key to species}

On generic level, Dryudella can be recognized with identification keys of Bohart \& Menke (1976) or Bitsch et al. (2001). The following key was compiled using the treatments of Giner Marí (1946), Pulawski (1959, 1961), Beaumont (1968), Kazenas (2000), Bitsch et al. (2001) and Schmid-Egger (2014).

\section{Males}

1. Frons completely black.

$1^{*}$ Frons with pale spot below ocelli. other Dryudella species

2. Abdomen completely black or black with yellow spots or bands. 3

$2^{*}$ Basal segments of abdomen red. Abdomen without yellow spots. 4

3. Abdomen completely black. Canary Islands. Dryudella sepulchralis (BEAUMONT, 1968)

$3^{*}$ Abdomen black with large yellow band on terga I-II. Anterior margin of clypeus medially with large triangular emargination. Israel.

Dryudella unicolor SCHMID-EGGER, 2014

4. Fore femur with yellow spot distally, fore tibia with yellow stripe basally, tarsi of all legs yellow to pale brown below. Body with long pale setae (Fig. 4). Egypt, Arabian peninsula.

Dryudella nephertiti (PULAWsKI, 1959)

$4^{*}$ Legs completely black, without yellow or brown pattern. Body (except for gena and propodeum) with long black setae (Fig. 1). Southern Morocco. Dryudella paulinae spec. nov.

\section{Females}

1. Basal terga of abdomen red, without yellow pattern.

$1^{*}$ Basal terga of abdomen black, or red with yellow spots. other Dryudella species

2. Apical clypeal margin rounded. Tibiae and tarsi red. Tegulae and wing base ivory white. Body with short and scattered setae. United Arab Emirates.

Dryudella deserti SCHMID-EGGER, 2014

$2^{*}$ Apical margin of clypeus with two teeth. Tibiae and tarsi black. Tegulae and wing base brown. Head and thorax with long and dense pubescence.

3. Fore femur distally and fore tibia distally with pale brown spot. Frons and vertex with long pale setae. (Fig. 5). Egypt, Arabian peninsula.

Dryudella nephertiti (PUlaWsKi, 1959)

$3^{*}$ Femur and tibia of fore legs black, without pale spots. Frons and vertex with long black setae, gena with long pale setae (Fig. 2), thorax (except for propodeum) with long black setae (Fig. 2). Southern Morocco.

Dryudella paulinae spec. nov.

\section{Acknowledgement}

We are very indebted to Dr. Christian SchmidEgger (Berlin) for the loan of Dryudella nephertiti, $D$. unicolor and D. deserti specimens, critical reading of the manuscript and correcting the English. Furthermore we thank the DAAD and the working group of
Prof. Dr. Norbert Jürgens for financial support as well as Dr. Manfred Finckh and Marleen Dalsass for their support during the field work. Paulina Zigelski was a great help in finding the best places for collecting flower visiting insects. 


\section{Literature}

Bitsch, J.; Dollfuss, H.; Bouček, Z.; Schmidt, K.; Schmid-Egger, C.; Gayuob, S. F.; Antropov, A. V. \& BARBIER, Y. 2001: Hyménoptères Sphecidae d'Europe occidentale. Volume 3. - Faune de France. France et régions limitrophes. Volume 86. - Fédération Française des Sociétés de Sciences Naturelles, Paris: 459_pp. -_ISBN: 978-2-903052-28-7 - https:// www.librairie-plumeetfabulettes.fr/livre/1716218-1 faune-de-france-hymenopteres-sphecidae-d-eurfederation-francaise-des-societes-de-sciences-n-

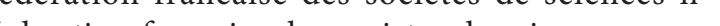
federation-francaise-des-societes-de-sciences- $n$.

BoHART, R. M. \& MENKE, A.S. $\overline{1976: S p h e c i d ~ W a s p s ~ o f ~ t h e ~}$ World. A generic revision - University of California Press, Berkeley, Los Angeles, London: IX + 695 pp.

De Beaumont, J. 1968: Sphecidae des Îles Canaries (Hymenoptera) - Bulletin of The British Museum (Natural History) Entomology_21: 245-278 - http:// iwww.biodiversitylibrary.org/part/31588'.

GINER MÀrí, J. 1946: Āstata paleárticas. Algunas Astata Latr. (Hymen. Sphec.) del Marruecos español y francés - Eos, Revista Española de Entomología 22: 7-15.

Kazenas, V. L. 2000: Digger wasps (Hymenoptera, Sphecidae) of Kazakhstan. Part 2. Subfamilies Pemphredoninae and Astatinae (in Russian) Ministerstvo Obrazovaniya i Nauki Respubliki Kazakhstan. Institut Zoologii, Almaty: 320 pp. https://archive.org/details/KazenasV.L.DiggerWaspsh'

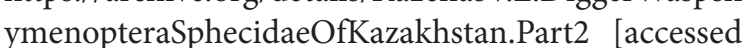
$2 \overline{0} \overline{1} \overline{7} / 0 \overline{2} / \overline{1} \overline{0}]$.
Pulawski, W. J. 1959: Espèces nouvelles ou peu connues du genre Astata Latr. (Hym., Sphecid.) - Polskie Pismo Entomologiczne 29: 359-416.

Pulawski, W. J. 1961: O dwóch gatunkach Sphecidae (Hym.) z Libanu. Sur deux Sphecidae (Hym.) du Liban - Polskie Pismo Entomologiczne 31: 93-96.

Pulawski, W. J. 2016: Dryudella (last updated 17 November 2016). In: Catalog of Sphecidae sensu _ato _ (= Apoidea _ excluding _ Apidae). _ hittp://researcharchive.calacademy.org/research/1 entomology/entomology_resources/hymenoptera/,

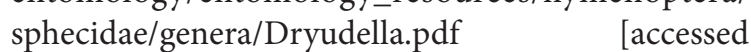
$2 \overline{0} \overline{16} / \overline{1} \overline{2} / \overline{1} 0]$.

Schmid-EgGer, C. 2014: Order Hymenoptera, families Crabronidae and Sphecidae. Further records and the description of new species: 521-631. - In: VAN Harten, A. (ed): Arthropod fauna of the UAE. Volume 5. - Dar Al Ummah, Abu Dhabi.

Schulz, O. 2008: The IMPETUS Climate Monitoring Network. - In: Schulz, O. \& JudEx, M. (eds): IMPETUS Atlas Morocco - Research Results 2000-2007. 3 Edition. - Department of Geography, University of Bonn, Bonn. 